\title{
Artikel
}

\section{Pleiten, schikken of slikken}

\author{
Een economische analyse van de Richtlijn inzake schadevorderingen bij inbreuken op het \\ mededingingsrecht
}

Peter van Wijck en Jan Kees Winters*

De Richtlijn inzake schadevorderingen beoogt de 'civielrechtelijke handhaving' van het mededingingsrecht te bevorderen door schadevergoedingsacties te stimuleren. De schade die door (met name) een kartel is veroorzaakt, dient geheel te worden vergoed. Economisch gezien betekent dit een extra financiële belasting bovenop de bestuursrechtelijke boete. Het lijkt dan aannemelijk dat de afschrikwekkende werking op kartelgedrag wordt vergroot. Of dat zo is, hangt af van diverse factoren, zoals de boete, pakkans, mogelijkheid tot schikken en de kans op het feitelijk verkrijgen van een schadevergoeding.

\section{Inleiding}

Op 10 november 2014 heeft de Raad van Ministers van de Europese Unie zijn goedkeuring gegeven aan de Richtlijn inzake schadevorderingen bij inbreuken op het mededingingsrecht. De richtlijn moet ervoor zorgen dat iemand die schade heeft geleden ten gevolge van een inbreuk op het mededingingsrecht, volledige schadevergoeding kan vorderen van de verantwoordelijke onder-

Dr. P.W. van Wijck is universitair hoofddocent aan de Universiteit Leiden. Dr. J.K. Winters is principal bij RBB Economics. De auteurs danken de redactie en Matthijs Visser voor hun commentaar op eerdere versies van dit artikel. neming(en). ${ }^{1}$ Met de richtlijn wordt vooral beoogd obstakels voor schadevordering weg te nemen. ${ }^{2}$ De richtlijn staat daarmee in het teken van volledige compensatie van schade.

De invloed van de richtlijn zal daarom vermoedelijk het grootst zijn indien het landen betreft waar private schadevergoedingsacties nog niet mogelijk waren. Maar ook voor die landen waar al wel schadevorderingen plaats-

1. Hieraan ging een lang traject vooraf. De Ashurst-studie uit 2004 (Study on the conditions of claims for damages in case of infringement of EC competition rules, comparative report, 31 augustus 2004) maakte duidelijk dat schadevorderingen in mededingingszaken in de EU van een '... astonishing diversity and total underdevelopment' waren (Ashurst, p. 1) en gaf aanleiding tot het Groenboek uit 2005 (Europese Commissie, Groenboek Schadevorderingen wegens schending van de communautaire antitrustregels, $\operatorname{COM}(2005) 672$ definitief): 'Terwijl het Gemeenschapsrecht bijgevolg een doeltreffend systeem vereist voor chadevorderingen wegens schending van de antitrustregels, staat in de 25 lidstaten het recht op dat gebied nog in zijn kinderschoenen (...). Het EHJ heeft geoordeeld dat bij gebreke van een communautaire regeling ter zake, de rechtsstelsels van de lidstaten moeten zorgen voor nadere voorschriften inzake het instellen van schadevorderingen. Aangezien de gemeenschapsrechter ter zake niet bevoegd is (behalve in het kader van prejudiciële procedures), zullen doorgaans de rechters van de lidstaten kennis nemen van dergelijke vorderingen. In de verschillende lidstaten bestaan er belangrijke belemmeringen voor de doeltreffende werking van schadevorderingen wegens schending van de communautaire antitrustwetgeving.' (Groenboek, p. 4). Zie ook bijvoorbeeld: E.-J. Zippro, 'Het richtlijnvoorstel betreffende schadevorderingen wegens mededingingsinbreuken', Tijdschrift mededingingsrecht en praktijk 2013, nr. 8; E. Oude Elferink en B. Braat, 'De richtlijn betreffende schadevergoedingsacties wegen inbreuken op mededingingsregels', NTER 2014/7; T. Raats, 'De (definitieve) richtlijn betreffende schadevorderingen wegens mededingingsinbreuken', M\&M 2014/5.

2. Daartoe formuleert de richtlijn regels op het gebied van bewijsgaring, verjaring en vaststelling van aansprakelijkheid van de inbreukmaker, het passing-on verweer en bewijs van schade en schadebegroting (ontleend aan T. Raats, 'De (definitieve) richtlijn betreffende schadevordering wegens mededingingsinbreuken', M\&M 2014/5). 
vinden, geldt dat de jurisprudentie nog niet is uitgekristalliseerd. Dit heeft belangrijke gevolgen voor de gepercipieerde kansen op succes in een schadevorderingszaak; immers, als een claimant denkt weinig kans te hebben op het winnen van een zaak, zal hij misschien niet eens effectief kunnen dreigen met een rechtszaak (en dus moeten 'slikken'). Omgekeerd: als hij denkt wel kans van slagen te hebben, dan kunnen de kartellisten nog denken dat zij ook zullen slagen en zal er geen schikking, maar een rechtszaak plaatsvinden ('pleiten', met alle extra kosten vandien).

Volledige compensatie vereist dus dat er niet alleen een juridische mogelijkheid tot schadevordering is, maar ook dat de ontwikkeling in de jurisprudentie en de (convergentie in) verwachtingen omtrent het winnen van een rechtszaak, zodanig zijn dat schikken de optimale uitkomst is. Ons artikel is bedoeld om dit inzicht op een zo eenvoudig mogelijke wijze te presenteren.

Indirect beoogt de richtlijn ook aan preventie bij te dragen. Indien een onderneming aansprakelijk is voor schade die ontstaat door mededingingsbeperkend gedrag, kan daarvan een prikkel uitgaan die maakt dat partijen van dergelijk gedrag afzien. De preventieve functie staat centraal in de economische analyse van het recht. ${ }^{3}$

\section{Economische analyse}

In dit artikel kijken we vanuit rechtseconomisch perspectief naar de richtlijn. In de rechtseconomie staan twee vragen centraal: welke consequenties heeft het recht voor gedrag en wat betekent dat voor de maatschappelijke welvaart? Er bestaat een zeer omvangrijke literatuur waarin verschillende rechtsgebieden langs deze lijn worden geanalyseerd. ${ }^{4}$ De kerngedachte is eenvoudig: rechtsregels beïnvloeden de voor- en nadelen die actoren aan bepaalde keuzes ontlenen. Daarom beïnvloedt recht gedrag. En daarmee beinvloedt het recht ook de maatschappelijke welvaart (de voor- en nadelen van alle partijen gezamenlijk). Rechtsregels zijn efficiënt indien ze per saldo de welvaart doen toenemen, terwijl inefficiënte regels per saldo juist meer kosten dan baten opleveren.

Neem bijvoorbeeld het contractenrecht. Dat recht is van belang voor de vraag of contractpartijen hun verplichting nakomen. Vanuit economisch perspectief zouden partijen ertoe moeten worden angezet om hun verplichting na te komen indien dat per saldo gunstig is voor de maatschappelijke welvaart (efficiënte nakoming). Indien nakoming per saldo ongunstig is voor de maatschappelijke welvaart, is dat juist niet zo (efficiënte

3. Het aansprakelijkheidsrecht kan verschillende functies vervullen. Dewees, Duff en Trebilcock maken daarbij onderscheid tussen preventie, compensatie en rechtvaardigheid. Ze merken op dat rechtseconomen vooral geïnteresseerd zijn in efficiëntie en daarmee de aandacht vooral richten op de preventieve functie van het recht. Zie D. Dewees, D. Duff en M. Trebilcock, Exploring the domain of accident law: taking facts seriously, New York/Oxford: Oxford University Press 1996, p. 5.

4. Zo bestaat er een, door Edward Elgar uitgegeven, negendelige Encyclopedia of law and economics. De delen gaan onder andere over eigendomsrecht, contractenrecht, aansprakelijkheidsrecht, procesrecht, strafrecht en mededingingsrecht (zie <www.elgaronline.com/abstract/nlmbook/9781782547457/9781782547457.xml>). contractbreuk). Er kan echter ook sprake zijn van inefficiënte nakoming (de maatschappelijke kosten van nakoming overtreffen de baten) of van inefficiënte contractbreuk (niet-nakoming, terwijl nakoming per saldo maatschappelijk voordelig zou zijn). ${ }^{5}$

Dezelfde redeneerlijn komen we tegen op strafrechtelijk gebied. ${ }^{6}$ De gedachte is dat een potentiële wetsovertreder een keuze maakt op basis van een afweging van de verwachte baten en de verwachte sanctie. Uit economisch perspectief is het van belang dat inefficiënte wetsovertredingen effectief worden ontmoedigd, terwijl het ontmoedigen van efficiënte wetsovertredingen uit welvaartsperspectief juist onwenselijk is.

Ook regelingen op het gebied van de mededinging zijn veelvuldig langs deze lijn geanalyseerd. Zo kan, bijvoorbeeld, voor een Europese richtlijn worden nagegaan welke consequenties voor gedrag te verwachten zijn. In het verlengde daarvan ligt dan weer de efficiëntievraag. Wordt inefficiënt gedrag ontmoedigd, terwijl voor efficiëntiebevorderend gedrag wel ruimte blijft bestaan?77 Vanuit dit perspectief kijken we in dit artikel naar de 'Richtlijn inzake schadevorderingen bij inbreuken op het mededingingsrecht'. Kort en goed: heeft de samenleving daar per saldo baat bij?

\section{Welvaart}

Over de vraag hoe kan worden vastgesteld welke invloed beperkingen van de mededinging hebben op de maatschappelijke welvaart, is een kleine bibliotheek volgeschreven. In handboeken op het terrein van de economische analyse van het mededingingsrecht is het dan ook een terugkerend thema. ${ }^{8}$ Gaat het over welvaart opgevat als de som van het consumentensurplus en het producentensurplus of alleen om het consumentensurplus? De teneur is dat in economische analyses doorgaans de totale welvaart als maatstaf wordt gehanteerd, ook al wordt in Europa beleidsmatig veeleer op consumentenwelvaart gericht. We volgen de in economische analyses gebruikelijke insteek en kijken dus naar de totale welvaart.

Terzijde: in de praktijk is het niet altijd relevant of naar de totale welvaart of naar (alleen) de consumentenwel-

5. Het begrip 'efficient breach' is in 1977 gemunt door Goetz en Scott: C. Goetz en R. E. Scott, 'Liquidated damages, penalties and the just compensation principle: some notes in an enforcement model and a theory of efficient breach', Columbia Law Review 1977.

6. De klassieke publicatie is van de hand van Gary Becker: G.S. Becker, 'Crime and punishment: an economic approach', Journal of Political Economy 1968

7. H.J. Hovenkamp, 'A primer on antitrust damages', 2011, zie <http:// papers.ssrn.com/sol3/papers.cfm?abstract_id=1685919>, p. 2: 'the damages for a particular offence should be calculated so as to make the offence unprofitable if it is inefficient, but not if it is efficient.'

Hovenkamp (2011, p. 7): 'An economic model for assessing the optimal level of antitrust damages will employ a deterrence rationale, making conduct unprofitable precisely to the extent that it is inefficient.' W.M. Landes, 'Optimal sanctions for antitrust violations', University of Chicago Law Review 1983, p. 653: 'The concept of an efficient violation is the key to determining the optimal antitrust penalty.'

8. Zie bijvoorbeeld: M. Motta, Competition Policy: Theory and Practice, Cambridge: Cambridge University Press 2001, p. 18-22. U. Schwalbe en D. Zimmer, Law and Economics in European Merger Cases, Oxford: Oxford University Press 2009, p. 6-8. S. Bishop en M. Walker, The Economics of EC competition Law, Londen: Sweet and Maxwell 2010, p. 29-32. 
vaart wordt gekeken. Er zijn echter omstandigheden waar het wel degelijk uitmaakt. Het kan zo zijn dat bijvoorbeeld horizontale samenwerking of een fusie niet alleen tot marktmacht (en daarmee een toename van de marktprijs) leidt, maar ook tot kostenbesparing. Het kan dan zo zijn dat deze samenwerking of fusie leidt tot een toename van de totale welvaart, maar ten koste van het consumentensurplus op de betreffende markt.

\section{Opbouw}

Het gedrag van potentiële kartellisten is natuurlijk niet alleen afhankelijk van het vooruitzicht dat de schade die ontstaat door mededingingsbeperkend gedrag moet worden vergoed. Er zijn meerdere manieren waarop het recht invloed uitoefent op mededingingsbeperkend gedrag. Dat geldt in het bijzonder voor het mededingingsrecht en de bestuursrechtelijke handhaving daarvan. In dit artikel beogen we daarom ook recht te doen aan de samenloop van de verschillende invloeden. Daartoe gaan we stapsgewijs te werk. We beginnen met de situatie waarin alleen langs bestuursrechtelijke weg invloed op het gedrag van potentiële kartellisten wordt uitgeoefend. De centrale gedachte daarbij is dat de combinatie van pakkans en bestuurlijke boete preventief kan werken. Daarna richten we ons op de invloed van civielrechtelijke aansprakelijkheid. Hier is de gedachte dat een preventieve werking uit kan gaan van het vooruitzicht, al dan niet via de rechter afgedwongen, schadevergoeding te moeten betalen. Ten slotte gaan we in op de situatie waarin beide invloeden tegelijkertijd aanwezig zijn.

Voor de goede orde merken we op dat we vooral geinteresseerd zijn in de gedrags- en welvaartseffecten van het tegelijkertijd bestaan van bestuursrechtelijke handhaving van het mededingingsrecht en de mogelijkheid om schade ten gevolge van mededingingsbeperkend gedrag te verhalen. We beogen dus zeker niet een analyse van alle aspecten van de richtlijn te geven.

\section{Bestuursrecht: pakkans en sanctie}

Indien partijen besluiten een kartel te vormen en daarmee inbreuk te maken op het mededingingsrecht, dan ontstaat daarmee de kans dat ze voor het maken van een inbreuk op het mededingingsrecht worden veroordeeld en een bestuursrechtelijke sanctie krijgen opgelegd. Deze kans en sanctie beïnloeden het gedrag van (potentiële) kartellisten. Dat is althans een centrale notie in de economische analyse van het (mededingings)recht. Actoren wegen de verwachte voor- en nadelen van handelingsopties en maken op basis daarvan een keuze.

\section{Voordeel}

Het voordeel van het vormen van een kartel is de te behalen toename van de winst. Door de vorming van een kartel kan de prijs op de markt toenemen en de hoe- veelheid afnemen. Ter bepaling van de gedachte kijken we hier naar het geval waarin de situatie die voorafgaat aan het vormen van een kartel correspondeert met de uitkomst die er onder volledige mededinging zou bestaan. In het marktevenwicht is de prijs dan precies gelijk aan het niveau van de marginale kosten. ${ }^{9}$ Voor de situatie die ontstaat nadat een kartel is gevormd, kijken we naar de situatie die overeenkomt met hetgeen resulteert onder monopolie. Het kartel zet een prijs die de winst maximaliseert. ${ }^{10}$

Figuur 1 illustreert de bedoelde verandering. ${ }^{11}$ In geval van volledige mededinging is de evenwichtsprijs gelijk aan de marginale kosten (MK). In het voorbeeld in Figuur 1 is de prijs (p) dus gelijk aan 40. De hoeveelheid (q) is dan gelijk aan 60. Een winstmaximaliserende monopolist zou een prijs van 70 vragen en daarbij een hoeveelheid van 30 verhandelen. ${ }^{12}$ De omzet van het kartel is dan dus gelijk aan $70 \times 30=2100$. Door het vor-

9. We beogen onze analyse door middel van het meest eenvoudige mode weer te geven, zodat we een aantal veronderstellingen maken, die uitsluitend dat tot doel hebben. Zo is het verder niet van belang, maar wel eenvoudiger om uit te gaan van constante marginale kosten en van volledige mededinging. Dit is overigens een gangbare manier van presenteren in schadevergoedingsacties: zie bijvoorbeeld de Praktische gids betreffende de begroting van schade bij schadeacties wegens inbreuken op artikel 101 of 102 van het Verdrag betreffende de werking van de Europese Unie (bij de Mededeling van de Commissie betreffende de begroting van schade bij schadeacties wegens inbreuken op artikel 101 of 102 van het Verdrag betreffende de werking van de Europese Unie), 13 juni 2013, PbEU 2013, C167/19, <http://ec.europa.eu/competition/ antitrust/actionsdamages/quantification_guide_nl.pdf>), p. 47. Zie ook: Oxera, 'Quantifying antitrust damages. Towards non-binding guidance for courts Study prepared for the European Commission', 2009, <http:// ec.europa.eu/competition/antitrust/actionsdamages/quantification_

study.pdf>, p. 14 en M. Visser en J.K. Winters, 'Berekening van schadevergoedingen in kartelzaken', SEW Tijdschrift voor Europees en economisch recht 2015/118. Als we deze veronderstellingen loslaten, blijft de essentie van de analyse hetzelfde, maar worden de berekeningen iets ingewikkelder (vgl. Oxera 2009, p. 14 onder Figuur 2.1).

10. De veronderstellingen dat de kartelprijs gelijk is aan de monopolieprijs en dat de betrokken afzet gelijk is aan de hoeveelheid die tijdens het kartel is gekocht zijn eenvoudig aan te passen en doen niet af aan de analyse. Voor meer informatie over de schadebepaling, zie de Praktische gids <http://ec.europa.eu/competition/antitrust/actionsdamages/ quantification_guide_nl.pdf>, Oxera 2009 en Visser en Winters 2015.

11. Op de horizontale as staat de hoeveelheid (weergegeven door ' $q$ '); op de verticale as de geldelijke waardes van prijs, marginale opbrengsten en marginale kosten, weergegeven door ' $p$ '.

12. Bij een winstmaximaliserend monopolie worden prijs en hoeveelheid bepaald door marginale opbrengsten $(M O)=$ marginale kosten $(M K)$, terwijl bij volledige mededinging de prijs en hoeveelheid worden bepaald door $M K=$ vraag. 


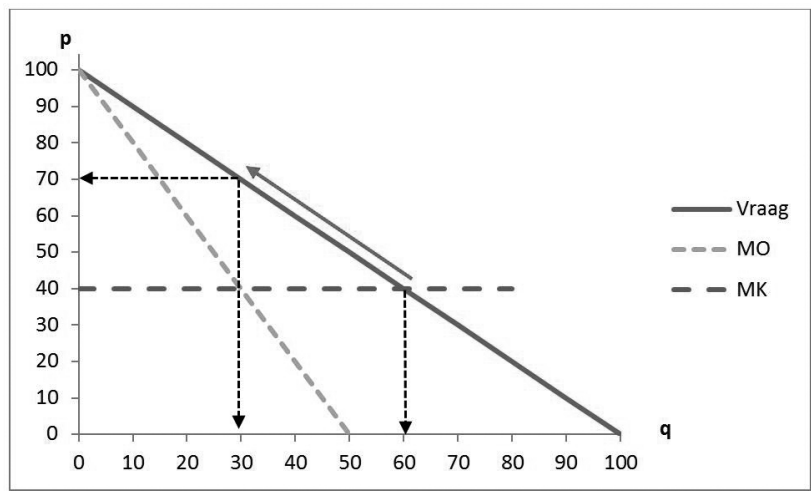

men van een kartel is een winst van $(70-40) \times 30=900$ te halen. ${ }^{13}$

\section{Nadeel}

De verwachte waarde van de bestuursrechtelijke sanctie is gelijk aan de kans op een sanctie maal de omvang van de eventuele sanctie. De boete is maximaal 10 procent van de omzet. In het voorbeeld is de boete dus maximaal 10 procent van 2100 , dat wil zeggen 210 . Indien de pakkans, bijvoorbeeld, 50 procent zou zijn, dan levert het vooruitzicht op een eventuele boete van 210 dus een verwachte sanctie van 105 op. ${ }^{14}$

\section{Weging voor- en nadelen}

Het vormen van een kartel wordt effectief ontmoedigd, indien het verwachte voordeel kleiner is dan het ver-

13. De winst bij volledige concurrentie in geval van afwezigheid van het kartel is hier nul, omdat we van constante marginale kosten uitgaan. Zouden we in plaats daarvan stijgende marginale kosten veronderstellen, dan was er wel winst gemaakt in de uitgangssituatie en zou het kartel door minder te produceren, nog een kostenreductie reduceren zodat de winst hoger wordt dan 900. Als de marginale kosten (MK) bijvoorbeeld worden bepaald door $2 / 3 q$, dan is de monopoliesituatie voor prijs en hoeveelheid hetzelfde (maar de winst wordt 1.500) en de evenwichtssituatie bij volledige concurrentie is dan dat q ongeveer gelijk is aan 43 en de prijs iets hoger dan 57 (met een winst van 1.224,5). Dit illustreert dat onder andere veronderstellingen de getallen wel veranderen (en het rekenwerk lastiger wordt), maar het principe (hogere prijzen, lagere hoeveelheden en hogere winsten) niet. Als we ook nog eens niet van volledige mededinging waren uitgegaan, maar bijvoorbeeld van Cournot-concurrentie, dan was de prijs in het evenwicht met Cournot-concurrentie (in geval van twee aanbieders, dezelfde vraagcurve en dezelfde constante marginale kosten) gelijk geweest aan 60 , zodat het kartel dan had geleid tot een prijsverschil van 10. In het Cournot-evenwicht hebben de ondernemingen een gezamenlijke winst van 800 , zodat door het kartel de winst met 100 toeneemt.

14. Strikt genomen is de maximale boete 10 procent van de wereldwijde omzet en niet van de bij het kartel betrokken omzet, zodat de boete als percentage van de betrokken omzet hoger dan 0,1 kan uitvallen. Dit valt in onze analyse eenvoudig op te lossen door niet de factor 0,1 te gebruiken, maar de factor $0,1 \mathrm{PQ} / \mathrm{pq}$, waarbij $\mathrm{PQ}$ staat voor de wereldwijde omzet en pq voor de betrokken omzet. Als de wereldwijde omzet gelijk is aan de betrokken omzet, resulteert de factor 0,1 en anders is deze hoger. We kunnen ook rekening houden met de zwaarte van de overtreding door de factor 0,1 te vervangen door $b(z)$, dat wil zeggen dat het boetepercentage $b$ afhankelijk is van de zwaarte $z$, zodat de toe te passen formule gelijk wordt aan b(z)PQ/pq, waarbij $b(z)$ een stijgende functie is van $z$ en als $z^{*}$ de zwaarste waarde representeert, $b\left(z^{*}\right)$ gelijk is aan 0,1 en bij lagere zwaartes is $b(z)<0,1$. We kunnen dit ook nog weergeven door $0,1 \gamma$, waarbij $\gamma \geq 1$, zodat het maximale boetepercentage (als percentage van de betrokken omzet) groter kan zijn dan 0,1 . Voor de afschrikwekkende werking betekent dit dat wel de getallen, maar niet het principe verandert. wachte nadeel. Als we ervan uitgaan dat de kartelwinst altijd wordt behouden dan is het verwachte voordeel gelijk aan de kartelwinst: het is logisch om hiervan uit te gaan omdat pas als het kartel effectief is geweest, het zowel winst als schade heeft opgeleverd. Het verwachte nadeel is de kans dat het kartel wordt gepakt maal de dan te betalen boete (dus 105). Hoe hoger de pakkans des te groter het verwachte nadeel. We kunnen op zoek naar de pakkans waarbij het verwachte voordeel en het verwachte nadeel precies aan elkaar gelijk zijn. Ligt de feitelijke pakkans daarboven, dan zal het kartel effectief worden ontmoedigd. In het cijfervoorbeeld ligt het omslagpunt bij een pakkans die groter zou moeten zijn dan één, wat natuurlijk niet kan en dus betekent dat het kartel altijd gesloten zal worden Dit betekent dat het kartel altijd per saldo winstgevend is, ook als het wordt gepakt. $^{15}$

\section{Efficiëntie}

In het bovenstaande voorbeeld doet de vorming van een kartel afbreuk aan de maatschappelijke welvaart. Dat is te zien door de situatie voor en na de vorming van het kartel met elkaar te vergelijken. Voor de vorming van het kartel, in de situatie met volledige mededinging,

15. Noem de kans dat het kartel wordt gepakt voor een inbreuk op het mededingingsrecht PM. Het verwachte voordeel is 900 . Het verwachte nadeel is dan $P M \times 210$. Het kartel wordt ontmoedigd indien $P M \times 210>$ 900. Dat wil zeggen $P^{M}>900 / 210$, ofwel $P^{M}>1$, wat hier betekent dat het kartel altijd voordelig uit is, ofwel dat de bestuurlijke boete 'te laag' is. In een algemene formule is de relatie tussen pakkans boete $P^{M}>W /$ 0,10 als $W$ voor de kartelwinst staat en $O$ voor de kartelopbrengst. Een uitgebreider theorie houdt er in dynamische zin rekening mee dat er in de loop der tijd per tijdseenheid een pakkans bestaat (en mogelijk zelfs één die hoger wordt, naarmate het kartel langer duurt). In dat geval beslist het kartel van periode tot periode of het door zal gaan of niet. Door de formule in symbolen te veralgemeniseren, kunnen we ook rekening houden met andere boetepercentages of andere veronderstellingen. In ons eenvoudige voorbeeld is de veralgemeniseerde pakkans voor de bestuurlijke boetesituatie gelijk aan $\mathrm{m} / 0,1$, waarbij $\mathrm{m}$ voor de monopoliemarge staat indien de marginale kosten constant zijn (dit is dus W/O). De veralgemeniseerde pakkans met (bijvoorbeeld) stijgende marginale kosten en een boete die rekening houdt met $0,1 \gamma$ ziet eruit als $(n+e) /(0,1 \gamma)$, waarbij ' $n+e^{\prime}$ gelijk is aan de winstmarge bij stijgende marginale kosten en waarbij ' $n$ ' het verschil tussen de monopolieprijs en de competitieve prijs meet (ten opzichte van de monopolieprijs) en waarbij 'e' de factor is die het extra effect op de winst meet die ontstaat omdat bij een lagere hoeveelheid lagere marginale kosten horen (deze is gelijk aan de prijs zonder het kartel minus de marginale kosten in de monopoliesituatie en dat geheel gedeeld door de monopolieprijs). De veralgemenisering geeft dus een iets uitgebreidere pakkansformule indien we de vereenvoudigde aannames loslaten. 


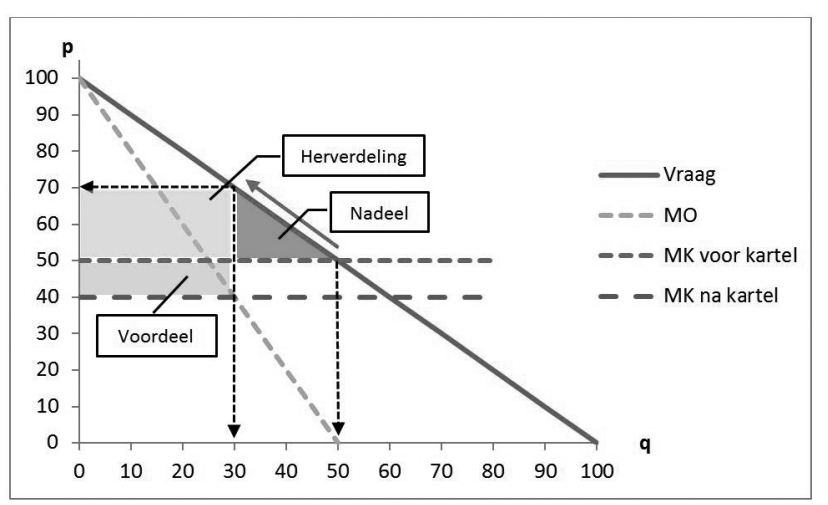

worden 60 eenheden verhandeld. Voor al die eenheden geldt dat de prijs die consumenten ervoor over hebben (wat blijkt uit de vraagcurve) groter is dan de marginale kosten. Daarom levert het verhandelen van die eenheden voordeel op voor consumenten. ${ }^{16} \mathrm{Na}$ de vorming van een kartel worden nog slechts 30 eenheden verhandeld. Dat impliceert dat er voordeel verloren gaat: dat is het 'dead meight loss' ${ }^{17}$ In die zin is de vorming van het kartel inefficiënt: degenen die deze eenheden zouden hebben gekocht bij een prijs van 40, zijn slechter af. Maar ook degenen die na de vorming van het kartel eenheden afnemen tegen een prijs van 70 zijn slechter af dan oorspronkelijk: wat zij erop achteruitgaan is precies gelijk aan hetgeen het kartel erop vooruitgaat. Dat is, kortom, een herverdeling ten gunste van het kartel.

\section{Efficiënte en inefficiënte kartels}

Zoals aangegeven in de inleiding komt in rechtseconomische analyses de vraag aan de orde of inefficiënte afspraken worden ontmoedigd terwijl efficiënte afspraken wel tot stand komen. In de woorden van Landes: 'The concept of an efficient violation is the key to determining the optimal antitrust penalty. ${ }^{\prime 18}$ Zo bezien zou het vanuit oogpunt van efficiëntie goed zijn indien inefficiënte afspraken worden verboden, terwijl efficiënte afspraken wel zijn toegestaan. ${ }^{19}$

In de literatuur wordt wel onderscheid gemaakt tussen efficiëntie en inefficiëntie fusies. In een beroemd artikel heeft Williamson uiteengezet dat een fusie niet alleen gepaard gaat met een toename van de prijs en een afname van de hoeveelheid, maar ook gepaard kan gaan met een daling van de kosten. Daardoor kan er per saldo

16. Producenten zijn bereid om extra te produceren zolang de consument bereid is meer te betalen dan het kost om extra productie te maken. Voor de monopolist pakt die afweging anders uit, zodat de monopolist minder aanbiedt dan bij concurrentie.

17. De omvang van het dead weight loss is gelijk aan $1 / 2 \times(70-40) \times$ $(60-30)=450$.

18. W.M. Landes, 'Optimal sanctions for antitrust violations', University of Chicago Law Review 1983.

19. Met een beetje goede wil is de combinatie van art. $101 \mathrm{VWEU} /$ art. 6 $M w$, lid 1 en lid 3 te zien als consistent met deze gedachte. sprake zijn van een efficiëntieverbetering. ${ }^{20}$ De redenering is niet alleen op fusies van toepassing. Evenzeer kan sprake zijn van efficiënte en inefficiënte kartels. ${ }^{21}$ Ook de vorming van een kartel kan gepaard gaan met kostenbesparingen (goedkopere productie of distributie) en efficiënt zijn. Vanuit economisch perspectief is dan de vraag hoe bereikt kan worden dat inefficiënte kartels worden ontmoedigd terwijl er wel ruimte is voor efficiënte kartels. Het is, met andere woorden, denkbaar dat een kartel tot een verlaging van de marginale kosten leidt. Figuur 2 geeft een voorbeeld van een efficiënt kartel, waarbij het voordeel dat voortkomt uit een verlaging van de marginale kosten groter is dan het dead meight loss dat ontstaat door de verhoging van de prijs. ${ }^{22}$ In dit voorbeeld zijn de marginale kosten vóór de vorming van een kartel gelijk aan 50 en na de vorming van een kartel gelijk aan $40 .{ }^{23}$ Voorafgaand aan de vorming van een kartel is er sprake van volledige mededinging, zodat er dan een prijs van 50 en een hoeveelheid van 50 tot stand komen. Ná de vorming van een kartel resulteert een monopolie; de winstmaximaliserende prijs is dan, precies zoals in het voorbeeld in Figuur 1, gelijk aan 70 en daarbij worden 30 eenheden verhandeld.

Door de daling van de marginale kosten ontstaat een voordeel. Dat voordeel is gelijk aan $30 \times(50-40)=300 .^{24}$ Tegelijk ontstaat een dead meight loss. Dat komt omdat er 30 in plaats van 50 eenheden worden verhandeld. Dat leidt tot een nadeel ter grootte van $1 / 2 \times(50-30) \times(70-50)$ $=200$. Per saldo is het kartel dus efficiënt omdat de

20. O. Williamson, 'Economies as an antitrust defense: the welfare tradeoffs', The American Economic Review 1968.

21. W.M. Landes, 'Optimal sanctions for antitrust violations', The University of Chicago Law Review 1983.

22. Vrij naar: G. Niels, H. Jenkins en J. Kavanagh, Economics for Competition Lawyers, Oxford: Oxford University Press 2011, p. 337. Oorspronkelijk: O.E. Williamson, 'Economics as an antitrust defence: the welfare tradeoffs', American Economic Review 1968.

23. En correspondeert dan met de situatie uit Figuur 1.

24. Merk op dat de consumenten weliswaar een hogere prijs voor minder eenheden product betalen en dus schade ondervinden, maar dat is gelijk aan extra winst voor de ondernemingen, zodat hier sprake is van herverdeling. Los van de vraag of deze herverdeling terecht is of niet, valt het in termen van betrokken financiële voor- en nadelen tegen elkaar weg. 
voordelen groter zijn dan de nadelen. ${ }^{25}$ Deze weging van voor- en nadelen is de kern van de zogenoemde 'Williamson trade-off'.

Vanuit oogpunt van efficiëntie zou het mooi zijn indien recht en rechtshandhaving ertoe leiden dat de vorming van inefficiënte kartels wordt ontmoedigd, terwijl efficiënte kartels wel tot stand komen. In beginsel is dat te bereiken door het mededingingsrecht zelf door middel van de afweging onder artikel $6 \mathrm{Mw} / 101 \mathrm{VWEU}$, lid 3. Het bereiken van kostenbesparing kan immers, onder voorwaarden, een reden zijn om een kartel ongemoeid te laten. Hetzelfde kan door de schadevergoeding worden bereikt door de verwachte sanctie gelijk te maken aan de verwachte schade die een te vormen kartel teweegbrengt: de nadelen (schade) van het kartel kunnen worden bekostigd uit de voordelen, dus als het kartel efficient is, zal het doorgang vinden (en anders niet).

De werkelijkheid is echter weerbarstiger. Niet alle kartels worden door een mededingingsautoriteit beoordeeld, zodat efficiënte en inefficiënte kartels kans zien om te (blijven) bestaan. Dit creëert een pakkans, waardoor een kartel de afweging moet maken of de voordelen van het kartel opwegen tegen de verwachte boete. Dit zou bij een boetesystematiek (of schadevergoedingssystematiek) die geheel gebaseerd zou zijn op de verwachte schade nog goed uit kunnen pakken voor de welvaart. De boetesystematiek is echter voornamelijk op de omzet gebaseerd en kan dus te laag zijn. ${ }^{26}$ Inefficiënte kartels zien daarmee soms kans om te (blijven) bestaan en worden ten onrechte helemaal niet gepakt (en omgekeerd worden sommige efficiënte kartels ten onrechte als inefficiënt behandeld). Zo bezien valt niet te verwachten dat het vigerende systeem uit oogpunt van efficiëntie goed werkt.

In het vervolg van dit artikel richten we ons op inefficiënte kartels. ${ }^{27} \mathrm{Op}$ grond van het voorgaande concluderen we over deze kartels:

1. De minimale pakkans die nodig is om de vorming van een kartel af te schrikken, is te berekenen: de pakkans maal de maximale boete moet groter zijn dan het verwachte voordeel van het kartel. ${ }^{28}$

25. Merk ook op dat het hier gaat om een afspraak die tegelijkertijd (causaal gerelateerd) een kostendaling en marktmacht oplevert. De alternatieve situatie is daarmee volledige mededinging zonder de kostendaling. Daarom berekenen we het dead weight loss ten opzichte van de prijs van 50 en niet, zoals in Figuur 1 ten opzichte van een prijs van 40.

26. Dit blijkt uit ons voorbeeld indien het kartel altijd kartelwinst realiseert en alleen de boete betaalt van 10 procent van de kartelomzet: dat is in ons voorbeeld altijd voordelig en er worden inefficiënte kartels gesloten.

27. Theoretisch gezien zou een efficiënt kartel dat ten onrechte wordt aangepakt en een boete krijgt, alsmede een schadevergoeding moet betalen, meer dan de verwachte voordelen kunnen gaan betalen en daarmee ten onrechte niet worden aangegaan. Dit is welvaartsverlies. We zullen echter op dit type welvaartsverlies en afwegingen om een kartel te sluiten niet ingaan.

28. Uit ons voorbeeld blijkt dat de bedoelde minimale pakkans wordt bepaald door de specifieke aannames en de parameterwaarde, bijvoorbeeld $\mathrm{P}^{M}>\mathrm{m} / 0,1 \gamma$; of $\mathrm{P}^{\mathrm{M}}>(\mathrm{n}+\mathrm{e}) / 0,1 \gamma$, waarbij $\gamma$ kan variëren tussen 0 en een getal groter dan 1 die wordt bepaald door de verhouding tussen de wereldwijde omzet en de 'betrokken' omzet en de zwaarte van de overtreding. Een algemeen model zou hier rekening mee houden door een algebraïsche benadering
2. Met behulp van een bestuursrechtelijke aanpak is een deel van de kartels te ontmoedigen. Daarmee wordt een welvaartsverlies vermeden. Daar staan dan de kosten van bestuursrechtelijke handhaving tegenover. Welke van de twee groter is, is niet a priori te zeggen: dat is een empirische vraag.

3. Omdat met behulp van een bestuursrechtelijke aanpak slechts een deel van de inefficiënte kartels kan worden ontmoedigd, zullen er toch inefficiënte kartels worden gevormd. ${ }^{29}$

\section{Civielrechtelijke aansprakelijkheid: invloed op verwachte kosten}

Voor de analyse van de effecten van de richtlijn zetten we twee stappen. We kijken eerst naar civielrechtelijke aansprakelijkheid op zich. Daarna (in de volgende paragraaf) kijken we naar de vraag hoe de combinatie van bestuursrechtelijke handhaving (die hierboven is weergegeven) en civielrechtelijke aansprakelijkheid uitwerkt. Civielrechtelijke aansprakelijkheid kan in beginsel antwoord bieden op twee problemen. Ten eerste heeft de bestaande bestuursrechtelijk aanpak slechts een beperkte gedragsregulerende werking. Ten gevolge daarvan worden niet alle inefficiënte kartels afgeschrikt. ${ }^{30}$ Ten tweede is het zo dat degenen die door het kartel worden benadeeld daarvoor geen compensatie ontvangen bij de bestuursrechtelijke handhaving. Ze blijven dus met de schade zitten.

\section{Volledige schadevergoeding}

Partijen die menen nadeel te ondervinden van een kartel, kunnen het kartel aansprakelijk stellen voor de schade. Volgens artikel 3 van de richtlijn heeft een benadeelde recht op volledige schadevergoeding: 'Een volledige vergoeding brengt een persoon die schade heeft geleden, in de positie waarin die persoon zich zou hebben bevonden indien er geen inbreuk op het mededingingsrecht

29. We zullen in het vervolg de aanname maken dat het kartel één eenheid vormt. Dat is natuurlijk niet het geval en zeker niet wanneer de kartelleden ook individueel voor de schade kunnen opdraaien (de richtlijn houdt deze mogelijkheid open). Een model dat bijvoorbeeld recht wil doen aan het feit dat een kartel uit meerdere aanbieders bestaat met gedeeltelijk dezelfde, maar gedeeltelijk ook tegengestelde belangen, zou moeten uitgaan van 'joint and several liability' (zie bijvoorbeeld L.A. Kornhauser, 'Economic analysis of joint and several liability', in: J. Arlen (red.), Research handbook on the economics of torts, Cheltenham: Edward Elgar 2013, hfdst. 8). Hierin zullen vooral de mogelijkheid van claimen bij individuele karteldeelnemers en de gevolgen daarvan voor de gedragingen van de karteldeelnemers onderling, alsmede het probleem van de informatievereisten en -verstrekking een belangrijke rol gaan spelen. Dit zal dan tot een ingewikkelder, maar realistischer, speltheoretisch model leiden.

30. De boetesystematiek is voornamelijk op de omzet en niet op de verwachte schade gebaseerd en kan dus te laag of te hoog zijn. Te laag betekent dat een privaatrechtelijke schadeactie kan helpen om de effectieve afschrikking te verhogen. Te hoog betekent dat de privaatrechtelijke schadeactie in termen van afschrikking neutraal is, maar wel nog een schadevergoeding kan opleveren. 
was gemaakt.' Dit uitgangspunt staat bekend als 'the principle of full compensation'. ${ }^{31}$

Onder ideaaltypische omstandigheden leidt het uitgangspunt dat toegebrachte schade volledig moet worden vergoed, tot een efficiënte uitkomst. ${ }^{32}$ De redenering ligt voor de hand: indien een partij overweegt een handeling te ondernemen die schade toebrengt aan derden en hij weet dat hij de rekening gepresenteerd krijgt voor die schade, dan zal hij die handeling alleen ondernemen indien het daarmee te behalen voordeel groter is dan het nadeel voor alle partijen gezamenlijk. Dat wil zeggen: alleen indien de som van de maatschappelijke voordelen groter is dan de som van de maatschappelijke nadelen.

Het is eenvoudig te zien dat het inefficiënte kartel uit Figuur 1 niet tot stand zal komen indien het kartel de daarmee toegebrachte schade volledig moet vergoeden. De eerste vraag is dan hoe groot 'de volledige schade' in dit geval is. In Figuur 1 kunnen we zien dat de prijs door de vorming van het kartel stijgt van 40 naar 70 . Dat betekent dat degenen die het goed kopen nadat het kartel is gevormd voor elke eenheid 30 'te veel' betalen. Volledige schadevergoeding impliceert dat het kartel die 'meerprijs' in de vorm van een schadevergoeding aan de benadeelde moet teruggeven. Daardoor levert het vormen van een kartel geen winst op (tenzij er een voldoende grote kostenbesparing tegenover zou staan, hetgeen bij een inefficiënt kartel niet het geval is). De vorming van het kartel wordt dan dus effectief ontmoedigd. Als ook de schade in de vorm van de niet gekochte eenheden vergoed zou moeten worden, wordt het effect versterkt dat een inefficiënt kartel niet wordt aangegaan. Het is natuurlijk wel lastig om vast te stellen wie deze schade heeft geleden, je moet immers vaststellen wie iets 'niet' heeft gekocht omdat de prijs is opgedreven door het kartel.

\section{Geschillen over schadevergoeding}

In de praktijk zal een kartel zich niet altijd gedwongen zien om toegebrachte schade spontaan volledig te vergoeden. Er kunnen, met andere woorden, geschillen ontstaan over schadevergoeding. Voor de analyse van dergelijke geschillen maken we gebruik van een standaardmodel uit de rechtseconomie, namelijk het zoge-

31. Zie bijvoorbeeld P.W. van Wijck en J.K. Winters, 'The principle of full compensation in tort law', European Journal of Law and Economics 2001.

32. De invloed van civielrechtelijke aansprakelijkheid op het gedrag dat mogelijk schade aan derden toebrengt, is uitgebreid geanalyseerd binnen de economische analyse van het recht. Zie voor een uitvoerige behandeling S. Shavell, Economic Analysis of Accident Law, Cambridge (Mass.): Harvard University Press 1987. In een ideaaltypisch geval zal de schadevergoeding gelijk zijn aan de feitelijke schade. In de praktijk kan de schadevergoeding lager uitvallen (bijvoorbeeld vanwege bewijsproblemen). De schadevergoeding kan echter ook hoger zijn dan de feitelijke schade: 'punitive damages'. noemde 'optimismemodel' ${ }^{33}$ De analyse loopt langs de lijn van drie vragen.

1. Kan iemand die schade heeft geleden geloofwaardig dreigen met het aanspannen van een rechtszaak tegen degene die de schade heeft veroorzaakt?

Als het antwoord op de eerste vraag positief is, dan volgt vraag 2 :

2. Kan de dader het best een voor het slachtoffer acceptabel schikkingsbod doen of kan hij het beter op een rechtszaak laten aankomen?

En ten slotte:

3. Doet de dader er, alles overziend, het beste aan om van zijn schadeveroorzakende activiteit af te zien? In deze laatste vraag komt de schaduwwerking van het recht tot uitdrukking.

We beginnen met de eerste vraag. De gedachte hierbij is dat iemand geloofwaardig kan dreigen met het aanspannen van een rechtszaak indien hij er naar verwachting op vooruitgaat. De redenering is eenvoudig: een benadeelde die een zaak aanspant, kan winnen of kan verliezen. Bij winst ontvangt hij een schadevergoeding; bij verlies is hij de proceskosten kwijt (in beginsel betaalt de verliezende partij zowel de eigen proceskosten als de proceskosten van de wederpartij). Stel dat de benadeelde denkt een kans van 80 procent te hebben op het winnen van een door hem aangespannen rechtszaak. Stel verder dat de schade 900 is (zie Figuur 1) en dat de proceskosten 100 zijn. In dat geval is de door de benadeelde verwachte netto-opbrengst van het aanspannen van een rechtszaak gelijk aan $0,8 \times 900-0,2 \times 100=700$. Dat is positief, zodat benadeelde geloofwaardig kan dreigen. ${ }^{34}$

Omdat de benadeelde geloofwaardig kan dreigen, komen we toe aan de tmeede vraag. Stel dat de dader, dat wil zeggen degene die schade toebrengt, in casu het kartel, de kansinschatting van de benadeelde deelt. Dat betekent dat het kartel denkt dat het 80 procent kans heeft op het verliezen van de zaak. Als het kartel verliest, moet het de schade vergoeden en de proceskosten dragen. De verwachte kosten van een rechtszaak zijn voor het kartel daarom gelijk aan $0,8 \times(900+100)=800$. Het kartel kan er echter ook voor kiezen om een voor de benadeelde aanvaardbaar schikkingsbod te doen. Daartoe zal hij (ten minste) 700 moeten bieden (de verwachte opbrengst van de benadeelde). Dat is minder dan de

33. De klassieke bijdragen zijn: J.P. Gould, 'The economics of legal conflicts', Journal of Legal Studies 1973. W.M. Landes, 'An economic analysis of the courts', Journal of Law and Economics 1971. R.A. Posner, 'An economic approach to legal procedure and judicial administration', Journal of Legal Studies 1973. S. Shavell, 'Suit, settlement, and trial: a theoretical analysis under alternative methods for allocating legal costs', Journal of Legal Studies 1982. Zie voor een overzicht: B.C.J. van Velthoven en P.W. van Wijck, Recht en efficiëntie, Deventer: Kluwer 2013.

34. Algemener: noem de kans die de benadeelde denkt te hebben op het winnen van een rechtszaak $P_{B}$, de hoogte van de schade(vergoeding) $S$ en de hoogte van de proceskosten $\mathrm{K}$, dan is de verwachte nettoopbrengst van het aanspannen van een rechtszaak voor de benadeelde gelijk aan $\mathrm{N}_{B}=\mathrm{P}_{\mathrm{B}} \times \mathrm{S}-\left(1-\mathrm{P}_{\mathrm{B}}\right) \times \mathrm{K}$. De benadeelde kan geloofwaardig dreigen met het aanspannen van een rechtszaak indien $N_{B}>0$. 
verwachte kosten van een rechtszaak. Dat impliceert dat een schikking aantrekkelijker is. ${ }^{35}$

Resteert vraag 3. Door het ondernemen van de schadetoebrengende activiteit gaat het kartel er enerzijds met 900 op vooruit en moet het anderzijds een schikking van 700 betalen. Het kartel is dus per saldo het beste af met kartelleren, indien we uitsluitend met de civielrechtelijke gevolgen rekening zouden hebben te houden en nog geen rekening houden met bestuursrechtelijke sancties. Dit vormt het onderdeel van de volgende paragraaf over de combinatie van bestuursrechtelijke handhaving en civielrechtelijke schadevergoeding. Alleen indien het zeker is dat de benadeelde een eventuele rechtszaak wint, wordt het kartel ertoe gedwongen om met de gehele schade rekening te houden. Immers, voor het kartel kost het dan 900 om een schikking tot stand te brengen, terwijl een rechtszaak hem naar verwachting 1000 kost. Het kartel zal in een dergelijk geval bereid zijn de gehele schade door middel van een schikking aan de benadeelde te vergoeden. Op dit punt komt het belang van jurisprudentie in beeld. Door de vorming van jurisprudentie wordt duidelijker hoe de winstkansen liggen. En daardoor zal het minder vaak tot een rechtszaak en vaker tot een schikking komen. Indien jurisprudentie ertoe leidt dat de posities van partijen volstrekt helder zijn, dan leidt dat tot een winstkans van 1 voor de ene partij en een winstkans van 0 voor de andere partij. In een dergelijk geval zal het nooit tot een rechtszaak komen. De ontwikkeling van jurisprudentie kan daarom leiden tot een afname van het aantal rechtszaken.

Concluderend: onder ideaaltypische omstandigheden leidt de verplichting om toegebrachte schade te vergoeden tot een efficiënte uitkomst, indien alleen sprake is van een civielrechtelijke schadevergoedingsactie. Alleen efficiënte kartels zien het licht, terwijl inefficiënte kartels juist niet tot stand komen. Immers: als zeker is dat het slachtoffer een door hem aangespannen rechtszaak tegen het kartel wint, zal het kartel zich gedwongen zien om de gehele schade te vergoeden. En dan zal het kartel alleen tot stand komen indien de schade kleiner is dan het te behalen voordeel. Maar dat betekent dus ook dat onder realistische omstandigheden, waarbij er onzekerheid bestaat over de uitkomst van een eventuele rechtszaak, niet gegarandeerd is dat de verplichting tot schadevergoeding tot een efficiënte uitkomst leidt.

\section{Combinatie van \\ bestuursrechtelijke handhaving en civielrechtelijke aansprakelijkheid}

Hiervoor hebben we achtereenvolgens gekeken naar bestuursrechtelijke handhaving van het mededingingsrecht en naar civielrechtelijke aansprakelijkheid voor schade die is ontstaan door inbreuken op het mededingingsrecht. Het is echter niet zo dat de Richtlijn civielrechtelijke aansprakelijkheid in de plaats komt van bestuursrechtelijk handhaving. Beide systemen zijn van kracht. En dat betekent dat beide systemen het gedrag van potentiële kartellisten beïnvloeden.

\section{Volgorde}

We veronderstellen dat de uitspraak van de bestuursrechter (of een bestuursrechtelijk orgaan) van belang is voor de vraag of benadeelden een kans maken bij het verhalen van schade op een kartel. We gaan er, met andere woorden, van uit dat een eventueel civielrechtelijk traject in de tijd na een eventueel bestuursrechtelijk traject plaatsvindt. Meer specifiek:

- Indien de bestuursrechter niet heeft uitsproken dat er sprake is van een inbreuk op het mededingingsrecht, dan gaan we ervan uit dat de vermeende benadeelde zichzelf kansloos acht in een civiele zaak.

- Indien de bestuursrechter mel heeft uitgesproken dat er sprake is van een inbreuk op het mededingingsrecht, dan kunnen benadeelden op grond daarvan menen een kans te hebben bij het verhalen van schade.

We gaan dus uit van een bepaalde volgorde. Eerst bestuur, eventueel daarna civiel. ${ }^{36}$ Indien de bestuursrechter heeft uitgesproken dat er sprake is van een inbreuk op het mededingingsrecht dan kan, zoals boven beschreven, een civielrechtelijk traject volgen. Als geschetst is daarbij van belang of de benadeelde geloofwaardig kan dreigen met het aanspannen van een rechtszaak en, zo ja, of het dan tot een schikking of een rechtszaak zal komen. Figuur 3 toont de samenhang tussen
35. Algemener: noem de kans die het kartel denkt te hebben op het winnen van een rechtszaak $P_{K}$, dan zijn de verwachte kosten van een rechtszaak voor het kartel gelijk aan $\left(1-P_{K}\right) \times(S+K)$. Een schikking is voor het kartel aantrekkelijker indien $P_{B} \times S-\left(1-P_{B}\right) \times K<\left(1-P_{K}\right) \times(S+K)$. Dat wil zeggen indien $P_{K}+P_{B}<1+K /(S+K)$. Een implicatie is dat het alleen tot een rechtszaak kan komen indien de subjectieve winstkansen van de partijen optellen tot een getal dat groter is dan 1. Vandaar dat dit model bekendstaat als het 'optimismemodel': beide partijen zijn er relatief (ten opzichte van elkaar) optimistisch over een rechtszaak te zullen winnen.
36. Indien de bestuursrechter geen inbreuk op mededingingsrecht heeft vastgesteld, dan gaan we ervan uit dat een benadeelde geen kans van slagen heeft indien hij een zaak tegen het (vermeende) kartel aanspant. In dat geval geldt $P_{B}=0$ en $P_{K}=1$. Er is dan voor het (vermeende) kartel geen enkele aanleiding om een schikkingsbod te doen en tot een rechtszaak zal het ook niet komen. Indien de bestuursrechter wel inbreuk op mededingsrecht heeft vastgesteld, dan heeft de benadeelde wel kans van slagen. Maar ook dan is niet automatisch zeker dat de benadeelde een rechtszaak zal winnen. Ook al heeft de rechter uitgesproken dat er sprake is van een inbreuk op het mededingingsrecht, dan nog staat niet vast dat de (vermeende) benadeelde ook schade heeft geleden ten gevolge van het gedrag van het kartel. Causaal verband moet dan nog bewezen worden. En dat kan mislukken. lets formeler: indien de bestuursrechter wel inbreuk op mededingingsrecht heeft vastgesteld, dan $P_{B}>0$ en $P_{K}<1$ (in bijzondere gevallen: $P_{B}=1$ en $P_{K}=0$ ). 


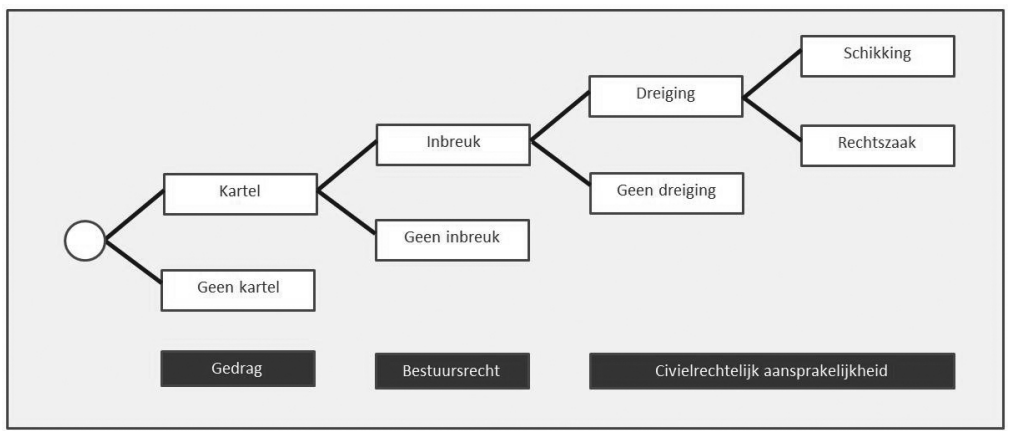

bestuursrechtelijke handhaving en civielrechtelijke aansprakelijkheid. ${ }^{37}$

De beslissing om al dan niet een kartel te vormen (links in Figuur 3) hangt af van het te verwachten vervolgtraject (rechts in de Figuur).

\section{Voorbeeld}

Om de werking van de combinatie van bestuursrechtelijke handhaving en civielrechtelijke aansprakelijkheid te illustreren, werken we een voorbeeld uit dat voortbouwt op de eerdere voorbeelden. Stel dat de kans op een bestuursrechtelijke boete 50 procent is en dat de eventuele boete 10 procent van de omzet van 2100 is, dus 210 . En stel dat civielrechtelijke aansprakelijkheid volgt in het geval het kartel gepakt wordt, hetgeen in het hierboven beschreven voorbeeld dan leidt tot een schikking ter grootte van 700 . In dat geval zal de vorming van het kartel effectief niet worden afgeschrikt. Immers, de verwachte winst voor het kartel is dan $900-0,5 \times(210+700)$ $>0 .{ }^{38}$

\section{Preventieve werking}

Kijken we in meer algemene zin naar de preventieve werking die er uitgaat van de combinatie van bestuursrechtelijke handhaving en civielrechtelijke aansprakelijkheid, dan is van belang op te merken dat deze werking afhankelijk is van de sterkte van de positie die de benadeelde in een eventueel civielrechtelijk geschil heeft.

Een zeer belangrijk aspect in de afweging om al dan niet een kartel te sluiten en dat medebepalend is voor de pakkans, is '/eniency'. Leniency is echter speltheoretisch niet zo gemakkelijk weer te geven in het analytische kader dat we presenteren (zie bijvoorbeeld P. Buccirossi, C. Marvao en G. Spagnolo, 'Leniency and damages', working paper no 32, Stockholm Institute of Transition Economics, februari 2015). Dit komt mede door de afwegingen die binnen het kartel door de kartelleden worden gemaakt: afwegingen die in onze analyse geen plaats krijgen omdat we het kartel als één speler behandelen. In Figuur 3 zou bijvoorbeeld de kans op een 'inbreukvaststelling' worden beïnvloed door leniency en door de afwegingen van de kartelleden om leniency aan te vragen (ten koste van de andere kartelleden). Dit zou ertoe leiden dat de bestuurlijke boete wordt ontgaan, maar een eventuele schadevordering niet. Dit betekent dat de schadevordering een kartel stabieler zou kunnen maken omdat de bestuurlijke boete (gedeeltelijk) wordt vervangen door de schadevordering in de afweging om leniency aan te vragen.

38. In dit geval is de pakkans die minimaal nodig is om de vorming van het kartel af te schrikken te berekenen uit $\mathrm{P} \times(210+700)=900$. Daaruit volgt een minimaal benodigde pakkans van $900 /(210+700)=99$ procent, dus net iets kleiner dan 1.
1. Als de benadeelde een zmakke positie heeft, dan zorgt civielrechtelijke aansprakelijkheid niet voor een versterking van de preventieve werking van het mededingingsrecht. Van een zwakke positie is sprake indien de verwachte netto-opbrengst van het aanspannen van een rechtszaak negatief is. Dat kan komen omdat de subjectieve winstkans van de benadeelde laag is, de eventuele schadevergoeding laag is of de proceskosten hoog zijn.

2. Als de benadeelde een sterke positie heeft, leidt civielrechtelijke aansprakelijkheid tot een versterking van de preventieve werking van het mededingingsrecht. Dat komt omdat de verwachte kosten voor de kartellist toenemen.

3. Als de benadeelde een sterke positie heeft, dan leidt dat niet automatisch tot een efficiënte uitkomst. Alleen indien de verwachte kosten voor de kartellist precies gelijk zijn aan de schade komt met zekerheid een efficiënte uitkomst tot stand. Er is echter niets in de combinatie van beide systemen wat ertoe leidt dat de verwachte kosten precies gelijk worden aan de schade. Zo bezien is er niets dat garandeert dat er een efficiënte uitkomst tot stand komt.

\section{Pleiten, schikken of slikken?}

In de vorige paragraaf hebben we gekeken naar de vraag hoe de combinatie van bestuursrechtelijke handhaving en civielrechtelijke aansprakelijkheid uitwerkt. Dat hebben we gedaan aan de hand van een voorbeeld. In dat voorbeeld hebben de partijen overeenkomstige kansinschattingen. We kunnen het voorbeeld veralgemeniseren om te laten zien hoe de pakkans, de bestuurlijke boete en de eventuele schadevergoeding samenhangen en welke factoren bepalend zijn voor de uitkomst of er:

- een kartel tot stand komt en zo ja, of dit gepakt en beboet wordt;

- schadevergoeding plaatsheeft;

- zodanige samenhang is dat de benadeelde (a) met lege handen staat, (b) een rechtszaak begint of (c) schikt.

Relevant is de vraag of afnemers (met name wanneer dit andere ondernemingen zijn die bij het kartel goederen en diensten inkopen die zij verder verwerken) de hogere inkoopkosten als gevolg van het kartel, kunnen afwentelen op hun eigen afnemers. Dit heet 'pass-on'. Als 'pass- 
on' mogelijk is, dan hebben deze afnemers (zelf) geen schade geleden en kunnen zij ook geen schadevergoeding claimen. Pass-on behandelen we in de volgende paragraaf.

\section{De optimale minimale pakkans}

We gaan weer uit van de gegevens van Figuur 1. Stel dat de kans op een bestuursrechtelijke boete $\mathrm{P}^{\mathrm{M}}$ is en de eventuele boete 10 procent van de omzet van 2100 is, dus 210. De verwachte kosten voor het kartel zijn dan $210 \times \mathrm{P}^{\mathrm{M}}$ als er alleen maar een bestuursrechtelijke boete zou bestaan. Aan de hand van het voorbeeld werken we uit wat de optimale uitkomst zou zijn en de mate waarin dat door de bestuursrechtelijke en civielrechtelijke acties wordt gerealiseerd.

De bestuursrechtelijke boete is 210 in het voorbeeld; de pakkans is $\mathrm{P}^{\mathrm{M}}$. Als de schadevergoeding precies gelijk is aan de schade van 900 (en deze is weer gelijk aan de winst), dan is de verwachte winst voor het kartel gelijk aan $900-\mathrm{P}^{\mathrm{M}} \times(210+900)$. Als deze verwachte winst negatief is, wordt het kartel afgeschrikt en komt het niet tot stand. De pakkans die de verwachte winst nul maakt, is gelijk aan 81 procent. ${ }^{39}$

Dus als de pakkans groter is dan 81 procent, dan is het kartel verliesgevend en wordt het niet gesloten. ${ }^{40}$ Deze pakkans is de optimale minimale pakkans. Minimaal omdat een hogere pakkans het kartel zeker afschrikt. Optimaal omdat zowel de volledige boete als de volledige schadevergoeding wordt betaald.

De minimaal vereiste pakkans

Omdat in theorie en praktijk geldt dat niet met zekerheid de volledige schadevergoeding zal worden betaald, zal de minimaal vereiste pakkans om een kartel te verhinderen hoger liggen dan de berekende optimale minimale pakkans. Zoals hiervoor geschetst, kan er worden geschikt (afhankelijk van de verwachtingen omtrent de uitkomsten van een proces) tegen een bedrag dat lager is dan de feitelijke schade. Er is dus een iets lagere verwachte kostenpost voor het kartel en dus een iets grotere prikkel om het kartel te sluiten: om dat weer te verhinderen, zal de pakkans omhoog moeten. Omdat de pakkans meestal niet kosteloos omhoog zal gaan, gaat dit ten koste van de totale welvaart.

We kunnen de uitkomst van schikken of een rechtszaak $\mathrm{U}$ noemen: $\mathrm{U}$ is kleiner dan of gelijk aan de hele schade van (in het voorbeeld) 900 . De verwachte winst voor het kartel is dan $900-\mathrm{P}^{\mathrm{M}} \times(210+\mathrm{U})$. De hiermee corresponderende minimaal vereiste pakkans is dan gelijk aan $900 /[210+U]$. Indien $U=900$, volgt de optimale minimale pakkans. In de meeste gevallen zal $\mathrm{U}$ niet gelijk

39. Ter toelichting: de verwachte winst is nul indien $900-P^{M_{x}}$ $(210+900)=0$. De pakkans $\mathrm{P}^{M}$ die daarvoor zorgt, is gelijk aan $900 /[210$ $+900]=900 / 1110=81$ procent

40. De gangbare manier in de praktijk om schadevergoeding te berekenen is door de kartelomzet (hier 2100) te vermenigvuldigen met de kartelopslag uitgedrukt in de kartelprijs, ook wel de meerprijs genoemd (hier: (70-40)/70). Merk op dat de kartelomzet gelijk is aan de kartelprijs vermenigvuldigd met de kartelhoeveelheid (hier 70×30). De schadevergoedingsformule wordt dan hier: $(70-40) / 70 \times(70 \times 30)=(70-40)$ $\times 30=900$. zijn aan 900, maar lager (een lager schikkingsbedrag of een lagere verwachte uitkomst van een proces) en dan volgt dat de minimale pakkans groter moet worden dan 81 procent.

Of er effectief gedreigd kan worden met een proces en of er dan een schikking of een rechtszaak volgt, kan geheel geanalyseerd worden zoals beschreven in de paragraaf over civielrechtelijke aansprakelijkheid. ${ }^{41}$ Als de schikking voor het kartel goedkoper is dan de rechtszaak zal er worden geschikt. En als de rechtszaak voor het kartel naar verwachting juist gunstig zal uitvallen, dan volgt een rechtszaak. Dat betekent dat de U die resulteert, afhankelijk is van de hoogte van het bedrag dat volgt uit schikken of een rechtszaak. Hiervan geven we twee voorbeelden.

Stel dat de benadeelde de kans op winnen van een proces op 0,9 schat en dus met die kans een volledige schadevergoeding ontvangt, maar met kans 0,1 opdraait voor de proceskosten. De verwachte winst voor de benadeelde is dan $0,9 \times 900-0,1 \times 100=800$. Dit levert een schikkingsbedrag van 800 op als het kartel denkt dat schikken beter is dan een rechtszaak. Dat laatste hangt af van de kans die het kartel denkt te hebben op het winnen van een rechtszaak.

Stel eerst dat het kartel denkt dat het de rechtszaak zal winnen met kans 0,5 . In dat geval verwacht het kartel dat het verwachte verlies van een rechtszaak gelijk is aan $0,5 \times(900+100)=500$. Deze verwachte waarde is lager dan het schikkingsbedrag en dus zal het kartel het op een rechtszaak laten aankomen. De waarde voor $\mathrm{U}$ is dan 500 en de minimaal vereiste pakkans is 900/ $[210+500]>1$ en het kartel zal gesloten worden. Als het kartel echter verwacht dat het een rechtszaak zal verliezen met kans 0,9 , dan zijn de verwachte kosten van een rechtszaak gelijk aan $0,9 \times(900+100)=900$ en dat is hoger dan het schikkingsbedrag. Er wordt dan geschikt en het bedrag voor $U$ wordt 800 . De daarmee corresponderende minimaal vereiste pakkans is 900/ $[210+800]=89$ procent .

Jurisprudentie

Deze voorbeelden illustreren dat de invloed van de richtlijn op schikkingen en schadevergoedingen sterk afhankelijk is van de ontwikkeling van de jurisprudentie. Hoe lager de verwachte waarde van $U$ (dus hoe geringer de verwachte opbrengsten van schikken of een rechtszaak), des te hoger de minimaal vereiste pakkans wordt. In het extreme geval dat $\mathrm{U}=0$, is het effect van de richtlijn nihil. Dit is het geval indien de benadeelde denkt een kleine kans te hebben op het winnen van een rechtszaak: de verwachte kosten van een proces worden dan te hoog en daarmee is er geen effectieve dreiging meer. De minimaal vereiste pakkans wordt 900/210>1 wat natuurlijk gelijk is aan de minimaal vereiste pakkans indien er alleen bestuursrechtelijke handhaving zou zijn. We kunnen daarom concluderen dat de richtlijn een positief effect heeft (de minimaal benodigde pakkans

41. Op verzoek sturen de auteurs graag het model op waarmee kan worden nagerekend wanneer en hoe een rechtszaak of een schikking volgt. 
verlaagt) als effectieve dreiging met een rechtszaak mogelijk is en dit tot schikken gaat leiden. Het lijkt aannemelijk dat dit (vooral) het geval zal zijn in die landen waar de richtlijn schadevergoedingen mogelijk gaat maken waar dat nu nog niet zo is. In landen waar de richtlijn al bij de praktijk aansluit, is het effect vermoedelijk geringer en zal dit vooral moeten komen van de rechtspraak en de (convergentie van) verwachtingen van partijen over hun winstkansen. ${ }^{42}$

De richtlijn legt in artikel 17 lid 2 vast dat het causale verband tussen kartel en gedraging een door het kartel weerlegbaar vermoeden wordt. De mogelijkheid bestaat dat dit sneller of gemakkelijker tot convergentie in de winstkansen leidt. Voor zover het om inefficiënte kartels gaat, hoeft dit geen probleem op te leveren. Voor zover het echter ook efficiënte afspraken of kartels zou treffen, bestaat het gevaar dat welvaartsverhogende afspraken en kartels worden afgeschrikt. Het ligt niet in de verwachting dat de optimale minimale pakkans wordt bereikt. De reden hiervoor is dat dit vereist dat de benadeelde een kans op het winnen van een rechtszaak heeft van 100 procent en het kartel een kans op verlies van de rechtszaak denkt te hebben van nul. In dat geval zal altijd voor het volledige schadebedrag worden geschikt en geldt dat $\mathrm{U}=900$ en de optimale minimale pakkans wordt gerealiseerd. Complicerende factor is daarbij dat de clementieregelingen ook worden beïnvloed: enerzijds vermindert de clementie de boete (mogelijk), anderzijds verhoogt ze (mogelijk) de kans op schadevergoedingen. ${ }^{43}$ Een andere complicerende factor is dat in de praktijk partijen asymmetrische informatie hebben en dat dit niet altijd kan worden gecorrigeerd. In dat geval ontstaat er een extra, speltheoretisch, probleem. ${ }^{44}$

\section{Pass-on}

We richten ons nu op het geval waarin pass-on mogelijk is. Indien afnemers zelf ondernemingen zijn, zullen ze hogere inkoopkosten die ontstaan indien hun toeleveranciers een kartel vormen in principe doorberekenen in hun eigen eindprijs aan de consument. In dat geval is het 'schadebedrag' voor deze directe afnemers geringer dan zoals bepaald door de meerprijs hierboven. Of en in welke mate de afnemers de inkoopprijs kunnen doorbe-

42. Het model wordt realistischer indien benadeelden hun claims coördineren of overdragen aan een entiteit die de claims wil schikken of voor de rechter brengen. Naar verwachting zal dit de kosten van het hele proces verhogen, wat de optimale minimaal vereiste pakkans verhoogt (er moet immers door individuele benadeelden een extra afweging over de te volgen strategie worden gemaakt), maar kan ook betekenen dat er juist meer claims komen omdat er een coördinatieprobleem wordt opgelost (wat de optimaal vereiste pakkans verlaagt).

43. Zie hierover bijvoorbeeld P. Buccirossi, C. Marvao en G. Spagnolo, 'Leniency and damages', working paper no 32, Stockholm Institute of Transition Economics, februari 2015, <www.learlab.com/pdf/ssrn id2566774_1_1424864820.pdf>.

44. Zie voor een algemene economische analyse van de rol van informatie in het procesrecht D. Baird, R. Gertner en R. Picker, Game theory and the law, Cambridge (Mass.): Harvard University Press 1994, hfdst. 8, 'Bargaining and information'. rekenen, hangt af van de concurrentievoorwaarden waaronder zij inkopen en verkopen. Hier zijn veel verschillende mogelijkheden voor, maar hieronder komen er twee aan bod:

a. De afnemers opereren zelf op een markt voor volledige mededinging.

b. De afnemer is een monopolist. ${ }^{45}$

De afnemers beschouwen de inkoopprijs als een gegeven.

\section{Volledige mededinging}

In het geval van volledige mededinging worden de inkoopkosten (betaald per eenheid product) als marginale kosten behandeld. Omdat in dat model de eindprijs aan consumenten gelijk is aan de marginale kosten, stijgt de eindprijs met de hogere inkoopkosten die het gevolg zijn van het kartel. ${ }^{46}$ In de eenvoudigste analyse van een model met volledige mededinging stijgt de prijs precies met de marginale kosten, dus er is dan ook volledige afwenteling van de hogere inkoopkosten als gevolg van het kartel in de verkoopprijs aan de consument. De afnemers van het kartel hebben zelf geen schade in de zin zoals hiervoor bedoeld. Het gevolg van het kartel is, net als hierboven, dat de prijs voor de consumenten stijgt: deze betalen de meerprijs. Er is dan ook geen wezenlijk verschil met het model hiervoor. ${ }^{47}$

\section{Monopolist als afnemer}

Als de afnemer zelf een monopolist is op zijn eigen afzetmarkt, ontstaat bij een kartel in principe het dubbele marginalisatieprobleem, dat wil zeggen dat de winstmarge van de monopolist en de winstmarge van het kartel worden gestapeld (omdat ze onafhankelijk van elkaar tot stand komen), waardoor de prijs voor de consument te hoog wordt. ${ }^{48}$ Dit zou tot verticale restricties

45. Dit kan worden vervangen door de veronderstelling dat de afnemer zelf enige marktmacht heeft, in welk geval hij zich evengoed als een monopolist zal gedragen: in die zin is de veronderstelling niet van belang. De nadruk ligt hier niet op de pass-on als zodanig.

46. Het kartel rekent een hogere prijs aan afnemers, zodat deze hogere inkoopprijs voor deze afnemers hogere marginale kosten oplevert, die daarmee weer een hogere eindprijs aan de consument oplevert.

47. Dit is geen algemeen geldende conclusie omdat de afnemers van het kartel niet noodzakelijkerwijs op dezelfde downstream markt opereren en omdat er sprake is van de (impliciete) veronderstelling dat marginale kosten constant zijn. Als deze aannames worden losgelaten, dan veranderen de conclusies ook. Het voert hier te ver om dit ook te behandelen. Zie bijvoorbeeld wel: F. Verboven en Th. van Dijk, 'Cartel damages claims and the passing-on defense', The Journal of Industrial Economics 2009, <http://onlinelibrary.wiley.com/doi/10.1111/j.1467-6451.2009. 00390.x/pdf>, of RBB Economics, 'Cost pass-through: theory, measurement, and potential policy implications', a report prepared for the Office of Fair Trading, 2014, <www.gov.uk/government/uploads/system/ uploads/attachment_data/file/320912/Cost_Pass-Through_Report. pdf>. Voor een beknopt overzicht zie RBB Economics, 'Pass-on in Damages Assessment: defence or offence?', RBB Brief 37, <www. rbbecon.com/wp-content/uploads/2012/06/rbb_brief_37.pdf > en 'The price effect of cost changes: passing through and here to stay', $R B B$ Brief 48, <www.rbbecon.com/downloads/2014/12/RBB_B48_Brief_ WEB.pdf>.

48. De prijs is ook te hoog vanuit het standpunt van de betrokken ondernemingen: als ze gezamenlijk zouden besluiten over de prijs en de (te verdelen) winstmarge, zou de prijs voor de consument lager uitvallen: de iets geringere gezamenlijke marge wordt meer dan gecompenseerd door de extra verkopen die door de lagere prijs worden gerealiseerd. 
tussen het kartel en de afnemer kunnen leiden, ${ }^{49}$ maar van deze complicatie zien we af. Het kartel van de toeleveranciers maakt de inkoopprijs voor de afnemer (de monopolist) gelijk aan de kartelprijs. Aangezien de hogere inkoopprijs met de eigen monopoliemarge van de afnemer wordt doorberekend aan de consument, gaat de consument meer betalen en minder afnemen: dit laatste effect is te vergelijken met wat in Figuur 1 is getekend. Omdat de afnemer nu zelf monopolist is, wordt de reactie van de consument om minder te kopen door de monopolist vertaald in een relatief lagere prijsstijging dan de inkoopkostenstijging: de inkoopkostenstijging wordt niet helemaal meer doorberekend aan de consument. Omdat de consument minder koopt, verliest de monopolist ook nog eens winst op deze verdwenen eenheden. De schadepost bestaat dan deels uit een hogere inkoopprijs voor zover deze niet wordt afgewenteld en deels uit verloren winst omdat de consumenten minder kopen. Of en in welke mate de monopolist in staat is om deze laatste schadepost aannemelijk te maken en te kwantificeren (en daarmee om de kans op schadevergoeding ervoor te vergroten), is nog een open vraag. Of het zin heeft om de verloren winsten ook als schade op te voeren, hangt van de kosten en opbrengsten ervan af: niet alleen nemen de mogelijke opbrengsten zelf toe, maar wellicht de kosten van de procesvoering ook en het kan zo zijn dat het de kans op winst in een rechtszaak verkleint omdat het ingewikkelder wordt om de bewijsvoering rond te krijgen.

Effectief betekent de gedeeltelijke 'pass-on' dat de monopolist (als benadeelde) nog slechts een deel van de hogere kartelprijs (en schade) kan terugvorderen in vergelijking tot de situatie waarin de consument de afnemer was. Deze lagere claim vertaalt zich in een relatief lagere $\mathrm{U}$ en dus ook in een relatief hogere minimaal vereiste pakkans.

\section{Conclusie}

In theorie lijkt de richtlijn een extra stimulans te bieden aan schadevergoedingsacties en de preventieve werking van het mededingingsrecht te versterken. Er wordt immers een groter bedrag aan financiële compensatie door het kartel gevraagd dan alleen de boete: dit verzwaart de sanctie en zou de kans op de keuze om tot een kartel te komen moeten verminderen. Dit kan worden gemeten door de minimaal vereiste pakkans. Als deze daalt door de richtlijn dan leidt dat ertoe dat meer potentiële kartels worden afgeschrikt. Hoewel dit conceptueel correct is, is de grootte van het effect en de mogelijkheid om volledige schadevergoeding te claimen geheel bepaald door een groot aantal factoren, waaronder in elk geval:

- de pakkans en de bestuursrechtelijke boete;
- de hoogte van de schadevergoeding die weer wordt bepaald door:

- de door benadeelde en kartel ingeschatte winstkansen in een proces;

- de proceskosten;

- bestaande jurisprudentie en de (mogelijke) ontwikkeling daarin;

- clementie-effecten;

- informatie-effecten;

- pass-on.

Deze factoren beïnvloeden alle de minimaal vereiste pakkans en kan deze doen variëren van de minimaal vereiste pakkans zoals die alleen door de bestuursrechtelijke boete wordt bepaald tot de optimale minimaal vereiste pakkans indien er kosteloos een volledige schadevergoeding wordt verkregen. Deze laatste situatie lijkt vooralsnog niet aannemelijk: door proceskosten, onzekerheid over de winstkansen in een proces, gevolgen van de clementieregeling en de informatiebehoefte wordt de uitkomst op een schikking of een rechtszaak beinvloed en daarmee de minimaal vereiste pakkans.

De invloed van de richtlijn zal daarom vermoedelijk het grootst zijn indien het landen betreft waar private schadevergoedingsacties nog niet mogelijk waren. Maar daarnaast zal de invloed van de richtlijn ook voor andere landen afhangen van de ontwikkeling in de jurisprudentie en de (convergentie in) verwachtingen omtrent het winnen van een rechtszaak.

Uit oogpunt van efficiëntie is van belang op te merken dat ook als inefficiënte kartels vaker zullen worden afgeschrikt, aan de afhandeling van civielrechtelijke claims kosten zijn verbonden (evenals aan de bestuursrechtelijke handhaving). Er bestaat ook een afruil tussen de bestuursrechtelijke en civielrechtelijke trajecten: wat meer van het een en wat minder van het ander kan tot dezelfde gedragseffecten leiden. Vandaar dat zich de vraag opdringt naar de optimale afruil tussen beide aanpakken: meer bestuursrechtelijke handhaving als dat relatief goedkoper is dan civielrechtelijke handhaving.

Hoewel het loslaten van een aantal vereenvoudigende veronderstellingen (eenheid van het kartel, eenheid van de benadeelde, de problemen omtrent het verkrijgen van informatie, ontbreken van een clementieregeling en dynamische aspecten) onmiskenbaar van belang zijn voor een realistische beschrijving, zal ook dan de uiteindelijke analyse neerkomen op het inschatten van kansen onder diverse scenario's en tegenacties voor benadeelden en karteldeelnemers. De in dit artikel gepresenteerde analyse geeft hiervoor de conceptuele basis. 